\title{
RESOURCE BASED VIEW AND THE IMPACTS OF MARKETING AND PRODUCTION CAPABILITIES ON INNOVATION
}

\author{
*Nurullah Genc \\ **Gönül Kaya Özbağ \\ $* * *$ Murat Esen \\ İstanbul Commerce University, Turkey \\ Kocaeli University, Turkey \\ İzmir Katip Çelebi University, Turkey
}

\begin{abstract}
Researchers have begun to focus on identifying organizational capabilities, but still relatively little is known on the types of business capabilities stimulating innovation. From this point forth, this study investigated the possible relationships among production capabilities, marketing capabilities and innovation. By the findings of this study we aim to reveal whether primary capabilities effect innovation or not and which one effect more. Many researchers suggest that capabilities can be determined via the value analysis of functional areas such as production, marketing, finance, research and development, human resource management (Snow and Hrebiniak, 1980; Hitt and Ireland, 1985; Acar, 1993; Hafeez, Zhang and Malak 2002;). Based on this common idea and aiming to contribute a better understanding of innovation in relation to capabilities, firstly, a brief review of resource based view is given and then production and marketing capabilities evaulated in this study are discussed. For this study a research model and hypotheses have been developed. In order to test the model and hypothesis, 122 organizations that are operating in Kocaeli, in Turkey were surveyed. Which capabilities can contribute positively to innovation is tried to be determined by regression analysis. As a result, according to the findings from this study, it can be said that there are significant relationships among marketing capabilities, production capabilities and innovation.
\end{abstract}

Keywords: Innovation, resource-based view, production capability, marketing capability

\section{INTRODUCTION}

The aim of this study is to contribute a better understanding of innovation in relation to functional capabilities. Especially in recent years, significant developments occured around the world, strengthen the belief, that the most important asset the firms have is their own capability. This paradigm enhances Resource Based View by emphasizing the fact that competitive advantage rests on the firm's possession of unique, difficult to imitate capabilities and resources. Drawing on these concepts, firstly, a brief review of innovation is given and then resource based view related with marketing and production capabilities evaulated in this study are discussed. We intend to establish a model integrating the related theories in resource based view and to develop a systematic tool that can help an organization to identify its capabilities boosting innovation.

\section{Literature Review And Hypotheses}

\section{Innovation}

Since innovation is so crucial in sustaining competitive advantage, many studies have investigated the innovation process (Maidque, 1980; Damanpour, 1989; Zirger and Maidique 1990; Dougherty and Hardy, 1996). Although there are number of innovation models, few have examined the relationship between innovation and business capabilities. The majority of studies have examined the significant effects of competences on firm performance or competitive advantage (Wernerfelt, 1984; Hitt and Ireland,1985; Barney, 1991; Amit and Schoemaker, 1993; Peteraf, 1993; Hafeez et al., 2002). So, it seems that there is a need in the literature on measuring the impact of functional capabilities on innovation. We believe that since innovation is a complex subject and characterized by low levels of understanding, the more emprically 
examined it in different industries and countries, the more easily it can be understood and applied by managers in organizations.

Many researchers who are interested in the topic of innovation defined it generally in similar ways despite some minor differences. Gopalakrishnan and defined innovation as programs, policies, systems, equipment, service, product, behavior or idea which is newly adapted to organization ( Shanthi and Fariborz, 2000: 15). Innovation represents the development of an entirely new product, service category, or production system, where knowledge experience are limited (Damanpour, 1989; Wolfe, 1994; Christensen and et al. 2003). Wang, et al., expresses that innovation is conceptually a process that begins with a novel idea and concludes with market introduction" (2010, p. 767). Most of the researchers and practitioner considered innovation as a positive and productive change but on the other hand it is a difficult task to succeed since it involves people, process and technology.

Zirger and Maidique who are well known for their efforts on innovation research tried to determine the key factors that affect product innovation. According to this researh findings, two of the five most important factors affecting product innovations are the product's value to the customer and the synergy of the new product with the firm's existing capabilities (Zirger and Maidique, 1990: 867). There are many researches which suggest that innovations with a closer fit to firm capabilities tended to be more succesful (Cooper and De Brentani, 1991; Cooper and Kleinschmidt, 1993; Kleinschmidt and Cooper, 1991; Song ve Parry, 1997a; 1997b; Zirger and Maidique, 1990). Danneels suggests that rather than trapping the firm, current capabilities may be used as leverage points to add new capabilities, which he refers to as "capabilities leveraging".

Similarly, Hamel and Prahalad (1994) recommended leveraging core capabilities as a faster and less risky way for the firm to grow and renew itself. They argued that in order to leverage core capabilities, managers need to escape a product-centric view of their firm, and examine the capabilities on which their products are based. According to Hamel and Prahalad (1994: 227) ' . . . in defining core competencies, managers must work very hard to abstract away from the particular product configuration in which the capabilities is currently embedded, and imagine how the capabilities might be applied in new product areas.' They argued that products embody capabilities, but capabilities are not product-specific. In other words, core capabilities transcend any particular product. One product may embody several capabilities, and one capabilities may underlie many products. Despite this potential and useful interchange, competences are not fully utilized by organizations and not all possible value is extracted from them.

\section{Resource-Based Theory}

Resource-Based Theory (RBT) and related concepts take place in many strategy formulation theories. Terms such as "strategic resources" (Barney 1991, Dierickx and Cool 1989), "distinctive competence" (Selznick 1957; Snow and Hrenibiniak, 1980), "core competence" (Hamel and Prahalad 1990), "invisible assets" (Itami and Numagani, 1992), "dynamic capabilities" (Teece, Pisano, and Shuen,1997) are used interchangeably by researchers that contributed to related literature. The well beloved researchers described resources and capability concept close and parallel to their views. Although they expressed in different words and ways, they basically tried to explain why some competitors are more succesful than others even they acquire nearly equal resources.

Let us describe resources before discussing why some enterprises are more succesful than others even they have nearly the same kind of resources. Resources are inputs into a firm's production process such as capital equipment, the skills of individual employees, patents, finance and talented managers (Thompson and Strickland, 1999: 91). Resource may include employee skills and experiences which a firm could employ though not "owned by a firm". In fact under a network organisation, resource includes all those assets, or have an access to in order to achieve its corporate goals. Some classify resources into three sub-categories, namely as physical assets, intellectual assets and cultural assets (Hafeez et.al, 2007). From this definitions one can exclude that resources can be both physical and intangible. RBT emphasizes the latter are more likely to be a source of sustained competitive advantage since global competition requires more knowledge integrated capabilities.

On the other hand, Grant identifies six catagories of resources; financial, physical, human, technological, reputation and organizational. He suggests that to understand a firm's ability to acquire competitive 
advantage, theorists need to make distinction between resources and capabilities. He claimed that instead of resources, capabilities which are the result of bundles of resources working together may give an enterprise competitive advantage. In other words, capabilities are emerged by the application of resources (Grant, 1991: 122). However every capability and resource doesn't create competitive advantage. In order to give a competitive advantage resources and capabilities have four charactericts as; valuable, rare (heterogeneous), inimitable (causal ambiguity, path dependent) and nonsubstitutable

A path-dependency arises from a series of events, occurring over time that would be difficult to duplicate. Causal ambiguity arises when the linkage between the firm resources and competitive advantage is not understood easily or imperfectly. Casually ambiguous resources are generally organizational capabilities. Some features of causally ambiguous patterns are tacit, and thus cannot be codified. Others may be quite apparent but cannot be completely observed. It is necessary that the firms possess both kind of resources and capabilities in order create competitive advantage (Dierickx and Cool; 1989, Collis and Montgomery; 2008) Understanding Resource-Based Theory (RBT) helps comprehension of competences. On the other hand, the competence-based view, also acknowledges resources, but mainly as deployable assets, governed by competencies (Urban, 2007: 395).

Helfat and Peteraf $(2003$; 999) define capability as " An organizational capability refers to the ability of an organization to perform a coordinated set of tasks, utilizing organizational resources, for the purpose of achieving a particular end result". Capabilities which are the building blocks of core competencies, including process and product design, product development, operations, value chain integration, all aspects of marketing and customer service, and organization design (Miller, Eisenstat and Foote, 2002: 44). Capabilities are argued to be dynamic when they enable firms to undertake new strategies to respond to changes in market conditions by combining and transforming available resources in new and different ways (Teece et al., 1997, p.511). There are many researchers who use the term 'capability' interchangeably with 'competence'since both of them can be formed by using the tangible and intangible value genarating assets and resources (Amit and Schoemaker, 1993; Dierickx and Cool, 1989; Grant, 1991; Teece, Pisano, and Shuen; 1997; Miller, Eisenstat and Foote, 2002). In this study we used them interchangeably too and especially follow the definition developed by Day (1994: 38) "capabilities are complex bundles of skills and collective learning exercised through organisational processes that ensure superior coordination of functional activities". They should include tacit knowledge, administrative skills and complex skills since they are emerged by a number of linking processes.

After defining resource and capability let us answer the question we have asked "why some enterprises are more succesful than others even they acquire nearly equal resources". According to RBT competitive advantage occurs when an enterprise differently combine physical and intangible resources and capabilities. No two companies are alike in their resources since they don't have the same tangible and intangible assets, set of experiences or organizational culture. Differences in company's resources and capabilites can explain a business' strength or weakness in the competition. These resources and capabilities determine how efficiently and effectively an enterprise performs its functional abilities. Thus RBT focus an analysis of external and internal environment (Wernerfelt,1984; Thompson and Strickland, 1999; Collis and Montgomery, 2008).

\section{Dimensions of functional capabilities}

In RBT literature, researchers have applied many perspectives to understand organizational competencies (e.g. expertise in disciplines, specific phenomena, technologies, and skills, functional skills) (Edgar and Lockwood, 2008; 23.) Among these different perspectives we follow the ones which suggest that an organizational competence usually includes functional skills (Snow and Hrebiniak, 1980; Hitt and Ireland, 1985; 2005; Acar, 1993; Hafeez, Zhang and Malak 2002; 2007). Most of the researchers agree that capabilities are developed by means of functional activities and for that reason internal analysis of the organization is critical. Hitt and Ireland $(1982 ; 267)$ investigated the main functions and categorized them as, general administration; production/operations; engineering and R\&D ; marketing; finance ; personnel; and public and government relations. However, in this study, production and marketing capabilities are investigated since they are key factors that affect the success of innovation. In the following section, each of these are shortly discussed to let daylight into the survey. 


\section{Production Capabilities And Innovation}

Cleveland, Schroeder and Anderson (1989) defined production competence as "the preparedness, skill, or capability that enables manufacturers to prosecute a product-market specific business strategy" (p. 657). The skills or capabilities possible for manufacturers are diverse, as the nine categories CSA identify indicate: adaptive manufacturing, cost- effectiveness of labor, delivery performance, logistics, production economies of scale, process technology, quality performance, throughput and lead time, and vertical integration. However in this research a total of six surrogate variables are used to measure the production-related capabilities of a firm such as cost- effectiveness, quality performance, flexibility and differentiation.

Researches about the effects of production capabilities on innovation are worth to examine. For instance, Cooper examined the factors leading to new product success. The research provides a vital insight into the factors which separate the successes from the failures in industrial product innovation. According to this study, Cooper suggests that marketing and production capabilities are key factors that affect product outcome. Having technical and production synergy and proficiency and avoiding pricing the product higher than competitive alternatives are the most critical determinants of new product success. In addition, Cooper suggested that to succeed new products should capitalize not only on market expertises but also on R\&D and production capabilities (Cooper, 1979: 96).

An other important researh about the this subject is realized by Zirger and Maidique. Like Cooper, they found that marketing and production capabilities and coordination is positively related to product success and negatively related to failures. Morover, a technically superior product is positively related to successful outcomes and negatively related to failures. In addition, entering new markets or using new technologies requires that the firm develop new capabilities, a process that can be riskier and more time consuming than building upon an existing base. It is for this reason firms should choose projects that build upon the firm's existing technological, marketing, and organizational capabilities (Zirger and Maidique, 1990: 872).

Studies examining the relationship between production capabilities and business performance are often seen in the literature. But the number of studies examining the relationship between innovation and production capabilities is less. Experimental studies on the production capabilities and innovation, usually examined the variables such as; cost, differentiation, flexibility, quality, production knowledge and so on. In this study, the variables used in the production capabilities are developed from the works of Hitt and Ireland (1983), Vickery (1991), Vickery Droge and Markland (1993), Schmenner and Vastag (2006), Cooper (1979), Zirger and Maidique (1990).

\section{H1: A positive correlation exists between Production capabilities and innovation.}

\section{Marketing Capabilities And Innovation}

Day $(1993,1994)$ defines marketing capabilities as integrative processes designed to apply the collective knowledge, skills, and resources of the firm to the market-related needs of the business, enabling the business to add value to its goods and services and meet competitive demands. In his research on market-driven organizations. Day (1994: 38) defines capabilities as "complex bundles of skills and collective learning, exercised through organizational processes." In their study of the core competencies of the corporation, Prahalad and Hamel (1990) identify a firm's processes of market interaction and functional integration as core organizational competencies.

When the literature on marketing capabilities is examined it can be said that marketing capabilities improves the performance of new product development and business (Cooper, 1979; Zirger and Maidique, 1990; Sanchez and Elola, 1991; Li and Calantone, 1998). If the information obtained from the customer during marketing activities is combined with the organization's capabilities, this transformed information can lead to new products or services.

$\mathrm{Li}$ ve Calantone suggest that market knowledge capabilities in new product development is composed of three processes: (1) a customer knowledge process, (2) a competitor knowledge process, and (3) the marketing-research and development $(\mathrm{R} \& \mathrm{D})$ interface. A customer knowledge process refers to the set of behavioral activities that generates customer knowledge pertaining to customers' current and potential needs for new products. A competitor knowledge process involves the set of behavioral activities that generates 
knowledge about competitors' products and strategies. The marketing-R\&D interface refers to the process in which marketing and R\&D functions communicate and cooperate with each other ( $\mathrm{Li}$ and Calantone, 1998:14).

In this regard, Cooper confirm in his study including America, Canada and European companies that customer information system is a critical factor that increases the characteristics of the new product. Thanks to information obtained at the end of this process, organizations can determine the characteristics of product performance and confirm if the proposed features create real customer value or not (Cooper, 1992: 124). Similarly, Sanchez and Elola's work on 56 industrial organizations stressed customer information is the most important driving force in innovation process. In addition, by this way organizations can determine appropriate markets for the developed product and increase the performance of the new product ( Sanchez and Elola, 1991: 51).

Market capabilities enables interaction with customers which may lead to higher levels of product capabilities through better market intelligence and customer feedback. If a firm does not know its competencies, clear market communication and trustworthy interaction with customers is impossible. Second, firms need to determine the level of translation needed in order to meet customers' communication needs. Hereby, different customers (or customer groups) may have different requirements which should be reflected in a firm's marketing plan. An understanding of the different levels of translation is an important step towards a targeted and customer-focused communication which is relevant to customers and addresses issues in their language. Different communications (i.e. different levels of translation) may also serve as means to differentiate a firm from its competitors. While underlying process and product competencies may be similar, the communication may different there with addressing different parts of the market. Third, a firm needs to develop good translation skills. Having identified its competencies and the required level of translation are only the basis for efficient market communication. A firm's translation ability can be seen as part of its market capabilities as the translation ability enables interaction with customers and other actors (Ritter, 2006: 1035).

Marketing capabilities are effective in the process of new product development as well as the success of the new product. there is no demand for a good unless consumers are aware of the good's existence. Customers, also, need to be informed by all means (through salespeople or promotions) of the innovative technologies that the firm processes and of the future $R \& D$ initiatives undertaken by it. Advertising stock, however, is tested as not of great significance. Some researchers argue that the role of the firm lies not only in perceiving that there is an opportunity to serve consumers, but also in making the consumers perceive that opportunity. When consumers are not even aware that this offer of knowledge is available, the firm must then inform them. In summary, it will be beneficial for a firm to listen more attentively and regularly to its customers and to integrate its voice effectively into product R\&D and commercialization processes. (Kirzner, 1973; Xiong and Shang, 2007; Robertson and Yu, 2001). In marketing capability questionnaire parallel to literature review a total of five surrogate variables are used to measure the marketing -related capabilities of a firm such as customer knowledge, competitor knowledge and market knowledge.

H2: A positive correlation exists between Marketing capabilities and innovation.

\section{Figure 1. Hypothesized Research Model}

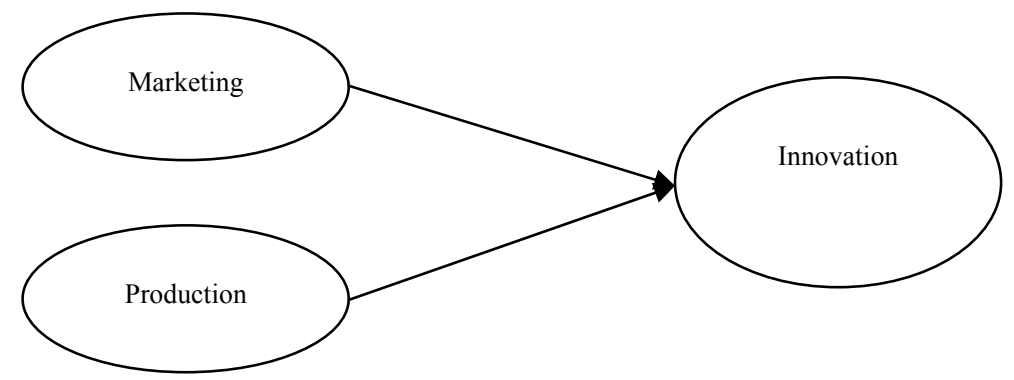




\section{METHODOLOGY}

\section{Research Goal}

In this survey we aim to identify the possible relationships among production capabilities, marketing capabilities and innovation.

\section{Selection of Sample and Respondents Demographics}

The study is empirical based on the primary data collected from 122 medium and large sized organizations that are registered in Kocaeli Chamber of Industry, operating in Kocaeli, one of the most important industrial cities in Turkey. Participation was optional for all respondents. Data was collected according to the preferences of managers; face to face interactions or electronic mail. Data obtained from questionnaires will be analyzed through the SPSS statistical packet program and PLS-Graph.

A majority of the respondents $(85,4 \%)$ were male. As to the educational qualification, $70,3 \%$ had obtained a university degree, and $(8,9 \%)$ held a postgraduate degree. $54,7 \%$ of the participants were aged between ( $31-$ $45)$ years and the majority of the participants $(59,4 \%)$ with job experience between $(1-5)$ years .

\section{Measures}

All items were measured on a five point Likert-type scale where (1) Strongly Disagree (2) Disagree (3) Neither Disagree nor Agree (Indecisive) (4) Agree (5) Strongly Agree.Three sections of the questionnaire are important for the present study; marketing capabilities, production capabilities and innovation. There are 18 questions in marketing and production capabilities. Production capabilities scale questions are developed from the works of Hitt and Ireland (1983), Vickery (1991), Vickery Droge and Markland (1993), Schmenner and Vastag (2006), Cooper (1979), Zirger and Maidique (1990). The questions about marketing capabilities are developed from Conant, Mokwa and Varadarajan's (1990) scale which is developed to measure distinctive capabilities.

Finally there are ten questions in innovation scale developed from the works of Prajogo and Ahmed (2006), Alegre and Chiva (2007), Hansen and Birkinshaw (2007).

\section{Data Analysis And Results}

The statistical analysis method used fort his study was partial least squares (PLS). The reason for using this technique is that PLS method can operate under limited number of observations and more discrete or continious variables. Therefore PLS method is an appropriate method for analysing operational applications. PLS is also a latent variable modeling technique that incorporates multiple dependent constructs and explicitly recognizes measurement error (Karimi, 2009). Also PLS is far less restrictive in its distributional assumption and PLS applies to situations where knowledge about the distribution of the latent variables is limited and requires the estimates to be more closely tied to the data compared to covariance structure analysis (Fornell and Cha, 1994).

Following the proposal of Straub (1989), we re-examined the survey instrument in terms of relaibility and construct validity although the scale questions were developed from items successfully used in previous surveys. First of all, the original survey which consists of 28 questions was analyzed by PLS-Graph program 8 item is found below the suggested loading value 0.70 and communal value 0.50 (Fornell and Larcker) and as suggested in literature these "below threshold" items are deleted (Hair, Tatham, Anderson and Black, 1998). Examination of the remaining items revealed that they adequately represent the underlying construct attesting to the content validity of the instrument. Tablo 1. indicates reliability scores of remained items. 
Table 1. Descriptive Statistics and Empirical Results of Measurement Model

\begin{tabular}{|c|c|c|c|c|c|}
\hline Const. \& Variables & & Loading & Communal & T-Statistics & \\
\hline \multirow{5}{*}{ Marketing Capabilities } & 1 & 0.81 & 0.66 & 22.78 & Composite \\
\hline & 2 & 0.88 & 0.79 & 41.23 & Reliability $=$ \\
\hline & 3 & 0.78 & 0.61 & 18.58 & 0.916 \\
\hline & 4 & 0.80 & 0.65 & 27.19 & $A V E=0.646$ \\
\hline & 5 & 0.84 & 0.71 & 30.91 & \\
\hline \multirow{6}{*}{ Production Capabilities } & 1 & 0.81 & 0.66 & 32.29 & Composite \\
\hline & 2 & 0.80 & 0.65 & 33.47 & Reliability $=$ \\
\hline & 3 & 0.75 & 0.58 & 16.83 & 0.916 \\
\hline & 4 & 0.86 & 0.75 & 39.26 & $A V E=0.646$ \\
\hline & 5 & 0.81 & 0.66 & 27.Tem & \\
\hline & 6 & 0.75 & 0.57 & 21.43 & \\
\hline \multirow{9}{*}{ Innovation } & 1 & 0.72 & 0.52 & 15.97 & Composite \\
\hline & 2 & 0.81 & 0.66 & 31.93 & Reliability $=$ \\
\hline & 3 & 0.82 & 0.67 & 34.90 & 0.926 \\
\hline & 4 & 0.74 & 0.55 & 15.20 & $A V E=0.594$ \\
\hline & 5 & 0.78 & 0.61 & 23.Eki & \\
\hline & 6 & 0.76 & 0.59 & 21.21 & \\
\hline & 7 & 0.77 & 0.60 & 18.77 & \\
\hline & 8 & 0.77 & 0.60 & 26.18 & \\
\hline & 9 & 0.75 & 0.56 & 18.58 & \\
\hline
\end{tabular}

As seen in Table 1 item reliability scores of scales is higher than the accepted 0.70 level and comminalities is higher than the accepted 0.50 level (Fornell and Cha, 1994). The results show composite reliability (CR) exceeding 0.8 as recommended by Nunnally (1978). AVE which can also be considered as a measure of reliability exceeds 0.5 as recommended by Fornell \& Larcker. Together CR and AVE attest to the reliability of the survey instrument. Composite Reliability and AVE values of scales are higher than the expected values.

\section{Table 2.Correlations between latent variables}

\begin{tabular}{llll}
\hline & 1 & 2 & 3 \\
\hline 1) Marketing Capabilities & 1 & & \\
2) Production Capabilities & 0.737 & 1 & \\
3) Innovation & 0.692 & 0.754 & 1 \\
\hline
\end{tabular}

According to the correlation results seen in Tablo 2, there is a positive and significant result between marketing capabilities and innovation (0.692) and also between production capabilities and innovation (0.754). Morover, there is a positive and significant result between latent variables; marketing capabilities and production capabilities $(0.737)$.

\section{Model Testing Results}

Figure 2 depicts the structural model showing path coefficients and $\mathrm{R}^{2}$ for dependent variable. 


\section{Figure 2. Structural model testing results}

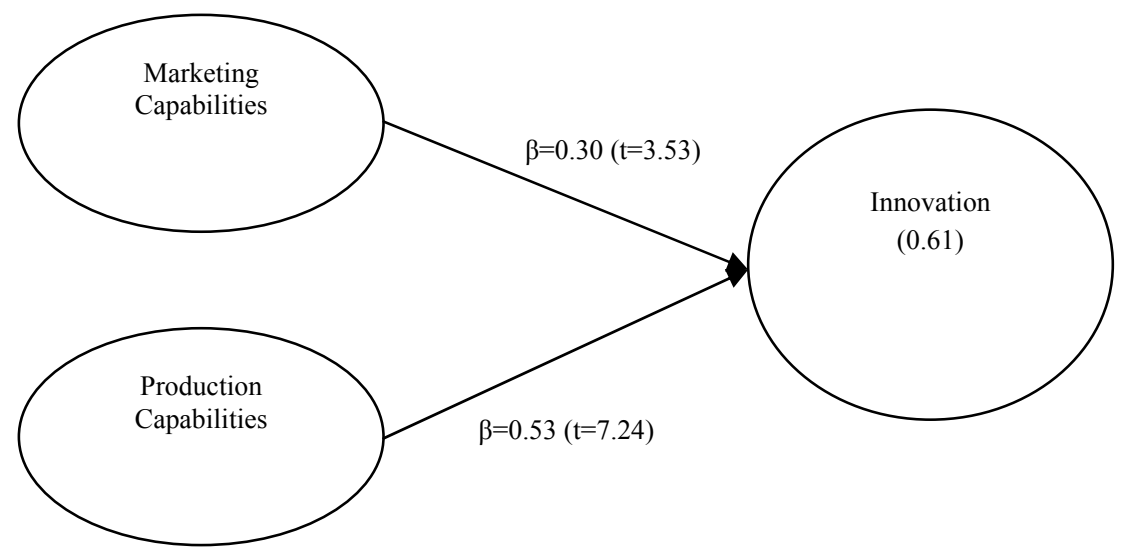

The $\mathrm{R}^{2}$ values for dependent variable indicate that the model was able to account for $61 \%$ of the variance in innovation. Bootstrap method was used in PLS-Graph to assess the statistical significance of the path coefficients. According to the results obtained from this research, marketing capabilities $(\beta=0.30 ; \mathrm{t}=3.53)$ and production capabilities $(\beta=0.53 ; \mathrm{t}=7.24)$ have a positive and significant effect on innovation.

\section{CONCLUSION AND IMPLICATIONS}

This study focuses exclusively on resources and capabilities inside firms. Generating and maintaining a good fit between capabilities and new product development is critic on the success of innovation. The findings of the many researches show that organizational capabilities have positive impacts on innovation and its success (Cooper and De Brentani, 1991; Cooper and Kleinschmidt, 1993; Kleinschmidt and Cooper, 1991; Song ve Parry, 1997a; 1997b; Zirger ve Maidique, 1990). Similarly, in this study, it is found that marketing and production capabilities have a positive and significant effect on innovation.

From the results of Pearson's correlation analysis, the correlation coefficients between the innovation and marketing and production capabilities were $(0.692)$ and $(0.754)$ respectively. Therefore, hypothesis $\mathrm{H} 1$ and $\mathrm{H} 2$ can be accepted. Morover, there is a positive significant relationship between marketing capabilities and production capabilities $(0.737)$ which are latent variables. The results also revealed that the effect of production capabilities on innovation is higher than marketing capabilities. This may be the result of the common belief that production capabilities more contribute to innovation-related activities such as developing new products, extending product ranges and improving existing product quality.

However this finding of the study shouldn't be interpreted as marketing capability is not a critical dimension in new product success since there are many researches which claim marketing capabilities improve the performance of new product development (Cooper, 1979; Zirger and Maidique, 1990; Sanchez and Elola, 1991; Li and Calantone, 1998; Xiong and Shang, 2007; Robertson and Yu, 2001) Marketing capability consists of the bundles of interrelated routines such as pricing, product, distribution, selling, advertising, promotion, marketing communication, and marketing planning, all of which effect the success of the new product. For instance, the study of Cooper (1979) in which he questioned "what makes a new product a success" illustrated that there are three facilitators to new product success related to marketing capabilities such as market knowledge (market information and activities); marketing communications and launch effort (sales force, advertising, promotion, and distribution); market need, growth, and size.

Similarly, Sanchez and Elola's work on 56 industrial organizations stressed customer information is the most important driving force in innovation process. Organizations would determine appropriate markets for the developed product and increase the performance of the new product by the help of the knowledge acquired in customer information process ( Sanchez and Elola, 1991). Morover, Zirger and Maidique stress that weak communication links and cooperation between the functional groups leads to critical konowledge loss that is needed for new product success (Zirger and Maidique; 1990). The implication of the mentioned studies is that market-oriented products are clearly more successful. Thus, market capabilities enables interaction with 
customers which may lead to higher levels of product capabilities through better market intelligence and customer feedback.

Therefore, it will be more beneficial for enterprises not to treat market capabilities and production capabilities as two seperate capabilities. Both of these capabililities has a unique function in enhancing innovation process. Market capability is an external capability that links an enterprise with the market; production capability is an internal capability that determines range of products, specialty,quality, cost, flexibility etc.Therefore, in innovation process both dimensions are important characteristics and when treated in an integrative approach enhance the effectiveness and efficiency of the firm in achieving its performance objectives and also innovation.

Finally, the results of this study provides theoretical and emprical contributions to RBV literature by showing that marketing and production capabilities enhance innovation. However, some other types of capabilities could play a critical role in innovation process such as HRM capabilities, financial capabilities, R\&D capabilities, cultural capabilities, entrepreneurial capabilities, management capabilities, logistical capabilities, global capabilities and etc. Therefore, it can be suggested to other researchers who wants to study in this subject to investigate these factors in different regions and markets. 


\section{REFERENCES}

Acar, Ahmet (1993). The Impact Of Key Internal Factors On Firm Performance: An Empirical Study Of Small Turkish Firms, Journal of Small Business Management, Oct93, Vol. 31 Issue 4, pp.86-92.

Amit Raphael and Schoemaker J. Paul (1993). Strategic Assets and Organizational Rent. Strategic Management Journal, C:14, No:1, pp.68-81

Angel M.Sanchez ve Luis Navarro Elola (1991). Product Innovation Management In Spain, Journal of Product Innovation Management, 8(1), pp.49-56

Alegrea Joaquin ve Chivab Ricardo (2008). Assessing the impact of organizational learning capability on product innovation performance: An empirical test, Technovation, 28 , pp.315-326.

Barney Jay (1991). Firm Resources and Sustained Competitive Advantage, Journal Of Management, 17(1), pp.99-120.

Christensen, Clayton M., Raynor, Michael E., Anthony, Scott D. (2003). Six Keys to Creating New Growth Business, Harvard Management Update, Vol. 8, Issue 1, pp.3-4.

Conant S. Jeffrey, Mokwa P. Michael, Varadarajan P. Rajan (1990). Strategic Types, Distinctive Marketing Competencies And Organizational Performance: A Multiple Measures-Based Study, Strategic Management Journal, V:11, No:5, September, pp.365-383.

Cleveland, G., Schroeder, R.G., Anderson, J.C. (1989). A theory of production competence, Decision Sciences 20 (4), 655-668.

Cooper Robert G. (1979). The Dimensions of Industrial New Product Success and Failure, Journal of Marketing, 43(3), pp.93-103.

Cooper Robert G (1992). The Newprod System; The Industry Experience, Journal of Product Innovation Management, 9 (2), pp.113-127.

Cooper Robert G (1988). The New Product Process: A Decision Guide For Management, Journal of Marketing Management, 3/3, pp.238-255.

Cooper, Robert G., De Brentani, Ulricke (1991). New Industrial Financial Services: What Distinguishes the Winners, Journal of Product Innovation Management, Vol. 8 Issue 2, pp.75-90.

Cooper, Robert G., Kleinschmidt, Elko J. (1993). Stage Gate Systems for New Product Success, Marketing Management, Vol. 1 Issue 4, pp.20-29.

Danneels Erwin (2002). The Dynamics of Product Innovation and Firm Capabilities, Strategic Management Journal, 23, September, pp.1095-1121.

Damanpour Fariborz et.al. (1989). The Relationship Between Types of Innovation and Organizational Performance, Journal of Management Studies, 26/6, pp.587-601.

Day S. George (1994). The Capabilities Of Market-Driven Organisations, Journal Of Marketing, V:58, October, pp.37-52.

Dierickx, I.; Cool, K. (1989). Asset Stock Accumulation and Sustainability of Competitive Advantage, Management Science; 35(12) pp.1504-1511.

Grant M.Robert (1991). The Resource-Based Theory Of Competitive Advantage: Implication For Strategy Formulation, California Management Review, Spring, pp.114-135.

Gopalakrishnan Shanthi and Damanpour Fariborz (2000). The Impact Of Organizational Context On Innovation Adoption in Commercial Banks, IEEE Transactions on Engineering Manegemant, 47(1), pp.1425.

Fornell C, Cha J. (1994). Partial least squares. Advanced methods of marketing research, 407, pp.52-78. 
Fornell, C., \& Larcker, D. F. (1981). Evaluating structural equation models with unobservable variables and measurement error, Journal of Marketing Research, 18, 39-50.

Hamel Gary and Prahalad C.K. (1994). Competing For The Future, Harvard Business School Press Books, 1384.

Hamel Gary and C.K. Prahalad (1990). The Core Capabilities Of The Corporation, Harvard Business Review, May-June, pp.80-90.

Hansen T. Morten and Birkinshaw Julian (2007). The Innovation Value Chain, Harvard Business Review,June, 85(6), pp.121-130

Hafeez Khalid Hafeez and Essmail Ali (2007). Evaluating Organisation Core Capabilities And Associated Personal Competencies Using Analytical Hierarchy Process, Management Research News, V:30, No:.8, pp.530-547.

Hafeez K., Zhang Y. and Malak N. (2002). Core Competence for Sustainable Competitive Advantage: A Structured Methodology for Identifying Core Capabilities, IEEE Transactions on Engineering Management, 49(1), pp.28-35.

Hitt A. Michael, Ireland R. Duane, Keats W. Barbara and Vianna Antonio (1983). Measuring Subunit Effectiveness, Decision Sciences, V:14, No:1, 87-102.

Hitt A. Michael, Ireland R. (1982). Functional importance and company performance: Moderating effects of grand strategy and industry type, Strategic Management Journal, 25(2): 265-296.

Itami, Hirovuki; Numagami, Tsuyoshi (1992). Dynamic Interaction Between Strategy and Technology, Strategic Management Journal, Special Issue, Vol. 13, pp.119-135.

Karimi J. (2009). Emotional labor and psychological distress: Testing the mediatory role of work-family conflict, European journal of social sciences, 11(4), 584-598.

Kleinschmidt, E. J.; Cooper, R. G. (1991). The Impact of Product Innovativeness on Performance, Journal of Product Innovation Management, Vol. 8 Issue 4, pp.240-251.

Li Tiger and Roger J. Calantone (1998). The Impact of Market Knowledge Capabilities on New Product Advantage: Conceptualization and Emprical Examinaton, Journal of Marketing, V:62, October, pp.13-29.

Ljungquist Urban (2007). Core Competency Beyond Identification: Presentation Of A Model, Management Decision, V:45, N:3, pp.393-402.

Ritter Thomas (2006) Communicating Firm Competencies: Marketing as Different Levels of Translation, Industrial Marketing Management, 35(8), pp.1032-1036.

Robertson, Paul L.; Yu, Tony F. (2001). Firm Strategy, Innovation and Consumer Demand; A Market Process Approach, Managerial \& Decision Economics, Vol. 22 Issue 4/5, pp.183-199.

Prajogo Daniel and Ahmed Pervaiz K. 2006. Relationships Between Innovation Stimulus, Innovation Capacity, And Innovation Performance, R\&D Management Vol. 36, Issue 5, pp.499-515.

Sanchez Angel M. and Elola Luis Navarro (1991). Product Innovation Management in Spain, Journal of Product Innovation Management, 8 (1), pp.49-56.

Schmenner W. Roger and Vastag Gyula (2006). Revisiting The Theory Of Producition Capabilities: Extensions And Cross- Validations, Journal Of Operations Management, 24(6), pp.893-909.

Snow , C.C. \& Hrebiniak, L. G. 1980. Strategy,Distinctive Competence and Organizational Performance, Administrative Science Quarterly, 25, pp.317-336.

Song, X. Michael; Parry, Mark E. (1997). Teamwork Barriers in Japanese High-Technology Firms: The Sociocultural Differences Between R\&D and Marketing Managers, Journal of Product Innovation Management, Vol. 14 Issue 5, pp.356-367. 
Song, X. Michael; Parry, Mark E. (1997). A Cross-National Comparative Study of New Product Deveiopment Processes: Japan and the United States, Journal of Marketing, Vol. 61 Issue 2, pp.1-18.

Teece D.J., Pisano G. and Shuen A. (1997). Dynamic Capabilities and Strategic Management, Strategic Management Journal, C:18, No:7, pp.509-533.

Thompson Arthur A., Strickland A. Alonzo (1999), Strategic Management: Concepts and Cases, McGrawHill Comp. Inc., 11. Ed., Singapure, 1-1049.

Xiong Wei and Shang Xiaoyan (2007). High-Tech Marketing Capabilities: A Comparative Study of Research Findings, International Management Review, 3(3), pp.66-75

Vickery K.Shawnee, Droge Cornelia and Markland E.Robert (1993). Production Capabilities and Business Strategy: Do They Affect Business Performance? , Decision Sciences, V:24, No:2, pp.435-456.

Vickery K. Shawnee (1991). A Theory Of Production Capabilities Revisited, Decision Sciences, V:22, No:3, pp.635-643.

Wernerfelt, Birger (1984). A Resource Based View of The Firm, Strategic Management Journal, Vol. 5 Issue 2, pp.171-180.

Wolfe R. (1994). Organizational Innovation Review, Critique and Suggestesd Research Directions, Journal of Management Studies, V:31, No:3, pp.405-431.

Zirger B. J. and Maidique M. A.( 1990). A Model of New Product Development: An Empirical Test, Management Science, V:36, No:7, pp.867-883. 